\title{
Apple Replant Disease: Causes and Mitigation Strategies
}

Traud Winkelmann ${ }^{1 *}$, Kornelia Smalla ${ }^{2}$, Wulf Amelung $^{3}$, Gerhard Baab 4 , Gisela GrunewaldtStöcker ${ }^{5}$, Xorla Kanfra ${ }^{2}$, Rainer Meyhöfer ${ }^{5}$, Stefanie Reim ${ }^{6}$, Michaela Schmitz ${ }^{7}$, Doris Vetterlein ${ }^{8,9}$, Andreas Wrede ${ }^{10}$, Sebastian Zühlke $^{11}$, Jürgen Grunewaldt ${ }^{12}$, Stefan Weiß ${ }^{1}$ and Michael Schloter ${ }^{13,14}$

${ }^{1}$ Institute of Horticultural Production Systems, Section Woody Plant and Propagation Physiology, Leibniz Universität Hannover, Herrenhäuser Str. 2, D-30419 Hannover, Germany

2Institute for Epidemiology and Pathogen Diagnostics, Julius Kühn-Institut, Messeweg 11/12, D-38104 Braunschweig, Germany

${ }^{3}$ Institute of Crop Science and Resource Conservation, Division Soil Science, Universität Bonn, Nussallee 13, D-53115 Bonn, Germany

${ }^{4}$ Competence Center of Horticulture, DLR Rheinpfalz, Campus Klein Altendorf 2, D-53359 Rheinbach

${ }^{5}$ Institute of Horticultural Production Systems, Section Phytomedicine, Leibniz Universität Hannover, Herrenhäuser Str. 2, D-30419 Hannover, Germany

${ }^{6}$ Institute for Breeding Research on Fruit Crops, Julius Kühn-Institut, Pillnitzer Platz 3a, D-01326 Dresden, Germany

${ }^{7}$ Department of Applied Science, Hochschule BonnRhein-Sieg, Von-Liebig-Str. 20, D-53359 Rheinbach, Germany

${ }^{8}$ Institute of Agricultural and Nutritional Sciences, Soil Sciences, Martin-Luther Universität HalleWittenberg, Von-Seckendorff-Platz 3, D-06120 Halle/Saale, Germany

9Department of Soil System Science, Helmholtz Center for Environmental Research, UFZ, TheodorLieser-Straße 4, D-06120 Halle/Saale, Germany

${ }^{10}$ Department of Horticulture, Landwirtschaftskammer Schleswig-Holstein, Thiensen 16, D-25373 Ellerhoop, Germany

${ }^{11}$ Institute of Environmental Research (INFU), Department of Chemistry and Chemical Biology, Chair of Environmental Chemistry and Analytical
Chemistry, Technische Universität Dortmund, OttoHahn-Str. 6, D-44221 Dortmund, Germany

${ }^{12}$ Institute of Plant Genetics, Unit Molecular Plant Breeding, Leibniz Universität Hannover, Herrenhäuser Str. 2, D-30419 Hannover, Germany

${ }^{13}$ Research Unit for Comparative Microbiome Analysis, Helmholtz Zentrum München, Ingolstädter Landstr. 1, D-85764 Neuherberg, Germany

${ }^{14}$ Chair for Soil Science, Research Department Ecology and Ecosystem Management, Technische Universität München, Emil-Ramann-Straße 2, D-85354 Freising, Germany

*traud.winkelmann@zier.uni-hannover.de

DOI: https://dx.doi.org/10.21775/cimb.030.089

\begin{abstract}
After replanting apple (Malus domestica Borkh.) on the same site severe growth suppressions, and a decline in yield and fruit quality are observed in all apple producing areas worldwide. The causes of this complex phenomenon, called apple replant disease (ARD), are only poorly understood up to now which is in part due to inconsistencies in terms and methodologies. Therefore we suggest the following definition for ARD: ARD describes a harmfully disturbed physiological and morphological reaction of apple plants to soils that faced alterations in their (micro-) biome due to the previous apple cultures. The underlying interactions likely have multiple causes that extend beyond common analytical tools in microbial ecology. They are influenced by soil properties, faunal vectors, and trophic cascades, with genotype-specific effects on plant secondary metabolism, particularly phytoalexin biosynthesis. Yet, emerging tools allow to unravel the soil and rhizosphere (micro-) biome, to characterize alterations of habitat quality, and to decipher the plant reactions. Thereby, deep insights into the reactions taking place at the root rhizosphere interface will be gained. Counteractions are suggested, taking into account that culture management should emphasize on improving soil
\end{abstract}


microbial and faunal diversity as well as habitat quality rather than focus on soil disinfection.

\section{Introduction}

Apple replant disease (ARD) affects plant propagation in nurseries as well as apple production worldwide by strongly reducing plant growth as well as fruit yield and quality (Mazzola and Manici, 2012; Manici et al., 2013). The disease occurs after repeated replanting of apple at the same site. On ARD soils, over the lifetime of an apple orchard, a $50 \%$ reduced profitability has been estimated due to later and less fruit bearing of the affected trees (Mazzola, 1998; Van Schoor et al., 2009). Problems by $A R D$ are increasing recently, mainly due to the concentration of tree nurseries to certain regions, such as the Pinneberg region in Germany or Pistoia in Italy, as well as due to the concentration of apple orchards in the respective fruit production areas. In addition, to achieve higher planting densities, the use of dwarf rootstocks results in a shorter life span of these orchards and in more frequent replanting (St. Laurent et al., 2010; Volk et al., 2015). A rapid improvement of this situation is unlikely, as installation costs increase (frost protection, irrigation) and areas for crop rotation become increasingly scarce due to alternative usage for industry, energy plants, or other purposes.

Various definitions of the term "replant disease" or related phrases such as "replant problem", "soil sickness" or "soil fatigue" exist (e.g. Klaus, 1939; Hoestra, 1968; Utkhede, 2006). According to Utkhede (2006) "replant problems" include both, abiotic and biotic factors which suppress plant growth, whereas "replant disease" comprises only all biotic factors. "Soil sickness" is used in cases, where the causes of the reduced growth are unknown or uncertain (Savory, 1966), thus excluding nematode damage (Spethmann and Otto, 2003). Here, we suggest the following definition of ARD: ARD describes a harmfully disturbed physiological and morphological reaction of apple plants to soils that faced alterations in their (micro-) biome due to previous apple cultures.

ARD is characterized by the specificity to the species Malus domestica (although cross reactions with other Rosaceae have been observed) and a persistence for decades (Savory, 1966). ARD is reversible after transplanting into virgin or healthy soil. Replant disease has also been reported for other plants, and especially members of the Rosaceae, such as cherry, peach, strawberry, rowan, and rose, are prone to it. In this review, we summarize current knowledge on the causes of ARD and critically evaluate current lines of research to develop mitigation strategies.

\section{Etiology and causes of ARD}

The species specificity implies that ARD has its origin in the apple plant-soil interface: Based on root exudates (Börner, 1959; Wittenmayer and Szabó, 2000; Hofmann et al., 2009) or/and by decomposition products of dead apple plant material changes in the biomes of the rhizosphere and of the soil are induced. A recent study addressed the composition of root deposits, thus analyzing the important root soil interface, of different apple rootstocks for the first time (Leisso et al., 2017). The rhizodeposits were found to be highly dynamic and influenced by growth conditions, rootstock genotype and bacterial communities of the rhizosphere. Also intraspecific allelopathy cannot be excluded in this context, but the persistence of ARD over decades would suggest that the involved toxic or deleterious substances are extraordinarily stable and bioactive. It is well accepted that soils may store or cycle certain molecules such as carbohydrates, lipids or proteins for years to decades (e.g. Wiesenberg et al., 2004; Derrien et al., 2006; Amelung et al., 2008). However, this has not been proven for root exudates, as usually these molecules are quickly transformed by rhizomicrobial respiration before being adsorbed or bound to soil minerals, which would make them inert against microbial degradation (e.g. Oades, 1988; Kuzyakov and Larionova, 2005; von Lützow et al., 2006; KögelKnabner and Amelung, 2014). If they do get bound, then it is questionable whether such compounds really maintain their bioavailability. From experiments with pollutants like polycyclic aromatic hydrocarbons, pesticides, or antibiotics, we know that with increasing contact time, newly added compounds become sequestered, thus rapidly losing their desorbability, bioavailability, and potential effectiveness on soil microbes (e.g. Hatzinger and Alexander, 1995; Lueking et al., 2000; Ciglasch et al., 2008; Rosendahl et al., 2012). It therefore appears truly unlikely that toxic compounds can explain ARD persistence for years. However, they may still trigger initial shifts in microbiome composition.

Shifts in bacterial and fungal communities in soil as a trigger for $A R D$ development

Previous studies allow the conclusion that ARD is assumed to be a disease-complex (Figure 1) which is influenced by the soil type and the climate of the 
respective site. The fact that soil disinfection leads to the restored regular plant growth clearly points to biotic causal factors (e.g. Mai and Abawi, 1981; Mazzola, 1998; Yim et al., 2013; Spath et al., 2015). In earlier studies on ARD soil microorganisms, various genera differing in dominance between sites were suggested to be involved in the disease complex. These are the oomycetes Pythium and Phytophthora, the fungi Cylindrocarpon and Rhizoctonia as well as actinomycetes and other bacterial genera like Bacillus and Pseudomonas (Jaffee et al., 1982; Otto et al., 1994; Mazzola, 1998; Utkhede, 2006; Tewoldemedhin et al., 2011). Also evidence for an involvement of root endophytic fungi (e.g. Cylindrocarpon-like fungi) in apple plant growth reduction on ARD affected soils was presented (Manici et al., 2013, 2018). More recently, numerous studies on microbial community analyses of ARD soils were published, strongly fostered by new sequencing technologies (Rumberger et al., 2007; Tewoldemedhin et al., 2011; Yim et al., 2013, 2015, 2016; Sun et al., 2014; Caputo et al., 2015; Franke-Whittle et al., 2015; Mazzola et al., 2015; Hewavitharana and Mazzola, 2016; Nicola et al., 2017). These total DNA based analyses confirmed previous data on changes in the microbial community composition in replant soils. Obviously, the soil-inherent microbial diversity, the plant species, and the plant growth stage influence the microbiome in the rhizosphere of apple plants. Differences are observed in the bacterial and fungal community composition in ARD affected and in healthy soils from the same site (e.g. Franke-Whittle et al., 2015). However, up to now it is unclear, whether the missing or additional microorganisms as well as shifts in abundances caused ARD or

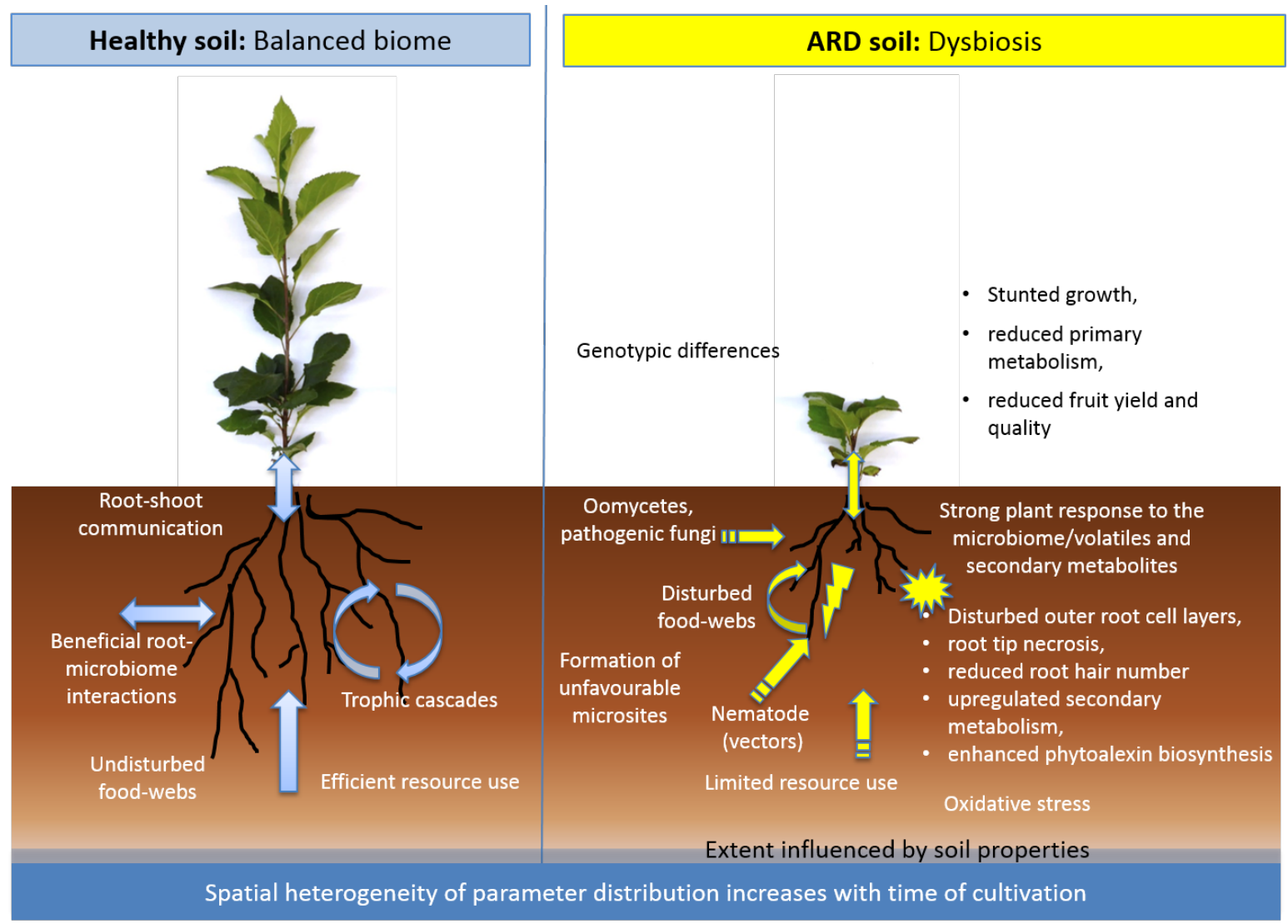

Figure 1. Apple replant disease (ARD) has multiple causes with a strong impact of dysbiosis regarding the microbiome and is influenced by soil properties, faunal vectors, and trophic cascades, with genotype-specific reactions. 
occurred as a result of ARD. The analysis of amplicon sequencing data of microorganisms in ARD soil after treatment with heat, gamma irradiation, Basamid $\AA$ or biofumigation revealed numerous bacterial and fungal populations with significantly increased abundance (responders) compared to that in untreated ARD soil. Although the 16S rRNA gene and ITS sequence data need a careful interpretation, notably, many of the responders belonged to taxa of which strains with plant beneficial traits or antagonistic activity were described, such as Burkholderia ssp., Arthrobacter ssp., Podospora ssp. or Penicillium ssp. (FrankeWhittle et al., 2015; Mazzola et al., 2015; Yim et al., 2016, 2017). However, the analysis of diversity revealed on the base of $16 S$ rRNA gene fragments or ITS fragments amplified from DNA directly extracted from soil (total community DNA - TC-DNA) is limited in its resolution down to the genus or species level depending on the used primer systems. But, for many species which colonize the rhizosphere, it is well known that traits differ on a strain specific level and bacteria of the same species can act as phytopathogens or plant growth promoting bacteria. Even the same strain can change the gene expression pattern depending on its environment and thus develops different interaction patterns with plant roots. Thus, analyses of the functions and the expression pattern of genes of interest provided by the below-ground microbiome are needed to improve our mechanistic understanding on the role of microbes in ARD development.

In upcoming studies oomycetes need to be included in the analysis by molecular tools as the primers targeting fungal ITS do not amplify oomycetes and thus these data are still missing. Furthermore, qPCR systems need to be established to determine the changes in abundance of potential harmful or beneficial microorganisms in the apple rhizosphere microbiome in response to different soil management treatments.

\section{Soil fauna affecting $A R D$}

Besides nematodes (see below), important soil mesofauna groups are Collembolans and soil mites, which play an important role in soil food webs as decomposers, plant parasites, microbivores as well as predators (Hopkin, 1997; Wardle, 2006, 2013; Walter and Proctor, 2013). Both groups of organisms are neither discussed in the context of causing agents nor considered at all in the current ARD literature (Utkhede, 2006; Mazzola and Manici, 2012; Vukicevich et al., 2016). Nevertheless, there is much evidence in the literature that soil mesofauna affects not only bacterial and fungal communities in the rhizosphere, i.e. by selective feeding on pathogenic or non-pathogenic microorganisms (Lartey et al., 1994; Sabatini and Innocenti, 2000, 2001; Innocenti et al., 2009; Böllmann et al., 2010), but also promotes mycorrhizal fungi (Steinaker and Wilson, 2008; Kanters et al., 2015) and other beneficial microorganisms (Lartey et al., 1994). Having in mind that Collembolans and soil mites are also strongly affected by land management (fertilizer, water, soil structure) (Schrader et al., 1997; Larsen et al., 2004; Innocenti et al., 2011; Roy et al., 2014) and pesticide use (Frampton, 2002; San Miguel et al., 2008; Chelinho et al., 2014), it would not be surprising that cascading trophic effects driven by consumers either directly or indirectly influence the etiology of ARD. So far, own results indicate decreased abundance of Collembola and soil mites, as well as shifts in Collembolan species composition in ARD compared to healthy soils (Meyhöfer et al., unpublished data).

Many studies suggested a role of root lesion nematodes in the ARD development (Hoestra and Oostenbrink, 1962; Dunn and Mai, 1972; Mai and Abawi, 1981; Jaffee et al., 1982) citing notably uneven distribution pattern of Pratylenchus penetrans in apple orchards (Mai and Abawi, 1978; Jaffee et al., 1982; Mai et al., 1994). Yim et al. (2013) inactivated nematodes in ARD affected soils by heat treatment and could prove that apple plants grew significantly better in heat-treated ARD soil compared to the untreated ARD soil, confirming the role of nematodes in ARD development. However, nematicide applications in affected orchards were inefficient to enhance apple growth (Hoestra and Oostenbrink, 1962; Covey Jr et al., 1979; Caruso et al., 1989; Mazzola, 1998). Furthermore, the low frequency of endoparasitic nematodes in roots did not give evidence for a contribution to growth reduction in apple in ARD affected soils (Manici et al., 2013). Nevertheless, root lesions induced by nematodes can cause synergistic damage to apple by acting in combination with some notable pathogenic fungi or oomycetes such as Rhizoctonia, Phytophthora, Cylindrocarpon, and Pythium (Mazzola, 1998). Furthermore, a high abundance of nematodes feeding on microbes can modify the microbial community by altering the relative abundance of populations (Djigal et al., 2004; HaiFeng et al., 2014; Gebremikael et al., 2016) thus causing a significant reduction of microbes that induce plant growth promotion. Indirectly, 
nematodes might contribute to ARD by dissemination of microbes (Freckman, 1988; Wang and McSorley, 2005) or activation of specific microbial growth by the release of growth limiting nutrients (Wang and McSorley, 2005). Recent findings by Adam et al. (2014) and Elhady et al. (2017) confirm specific bacteria and fungi to be attached to infective stages of Meloidogyne incognita and $P$. penetrans in different soil types indicating an ecological role of the association. Four way interaction between fungi, oomycetes, bacteria and nematodes was supposed to increase the ARD severity when these organisms were present at the same time (Utkhede et al., 1992; Mazzola and Mullinix, 2005).

\section{Soil properties affecting $A R D$}

Soil properties might modulate the degree of ARD observed in plants, if not even causally affecting it (von Bronsart, 1949). In general, sandy/light soils have often been observed to be more prone to ARD than loamy soils (http://www.leicesters.co.nz/ specific-apple-replant-disease/). Own observations additionally confirm that areas with high groundwater levels or extended periods of water logging are less conducive for ARD most likely due to interfering with the development of pathogenic aerobic communities.

Von Bronsart (1949) stated that physical soil conditions like compaction, loss of specific pore sizes, dryness in macropores or stagnant water conditions above a compacted plough pan, may hardly be seen as major cause of ARD, because the latter is plant-specific while most soil-related effects are not. Nevertheless, physical soil conditions may drive the survival and competitiveness of phytopathogenic or beneficial nematodes and also of microbial communities, i.e., they might affect the intensity and duration of ARD symptoms. And indeed, ARD has often been observed to occur heterogeneously at a given site, as do many soil properties (Bogena et al., 2010; Gebbers and Adamchuk, 2010; Herbst et al., 2012). Mazzola and Manici (2012) concluded that abiotic factors may exacerbate ARD but do not appear to function as the primary cause of the disease.

Among chemical soil properties influencing ARD severity, $\mathrm{pH}$ is certainly a master variable affecting nutrient availability, microbial diversity and microbial nutrient mobilization and immobilization. Some authors reported that in soils with low $\mathrm{pH}$ values (around 4-4.5) ARD problems are less pronounced (Jonkers et al., 1980; Utkhede, 2006), while others reported that low $\mathrm{pH}$ values make soils prone to replant disease problems (Willet et al., 1994). Additionally, the role of $\mathrm{pH}$ on ARD severity is obviously genotype dependent (Fazio et al., 2012).

With variations in $\mathrm{pH}$, nutrient availability changes, and there has been focus on micronutrient controls on ARD expression, mainly related to $\mathrm{Zn}, \mathrm{Fe}$, and Mo (von Bronsart, 1949; Fan et al., 2010; Fazio et al., 2012). To avoid additional nutrient limitations, apple replanting should consider respective fertilizer recommendations. These may include, for instance, the use of selected micronutrients such as zinc while possibly excluding or at least very carefully operating with others like boron (Tukey et al., 1984). Adding mineral fertilizer, e.g., with P, (Sewell et al., 1988), as well as managing ground cover by adding compost or even biochar, may induce increased biocontrol properties of soils including a reduction of nematodes causing root lesions. Fertilization may thus affect ARD severity in nutrient-limited soils (van Schoor et al., 2009), but frequently failed to replace fumigation for replanting in temperate climates (St. Laurent et al., 2008; Mazzola and Manici, 2012; Glisczynski et al., 2016; Peruzzi et al., 2017).

To future study the role of soil in modulating the degree of ARD in plants, it will be inevitable to map spatial ARD heterogeneity in different orchards and to correlate it with spatial patterns of soil properties that likely also include subsoil properties. The finding of causal interactions between soil properties and ARD, however, is often hampered by insecurity related to sampling rhizosphere soil. Rhizosphere soil is commonly obtained by a vigorous shaking of the uprooted root system. This enables neither to differentiate between affected and non-affected root areas, nor to define precisely the distance from the root surface. As in general less material is obtained from affected roots compared to healthy root material, a dilution of effects might occur using total root sampling approaches.

\section{Plant reactions to ARD}

The level of susceptibility differs significantly between individual apple genotypes. Fully resistant genotypes were never observed yet, but less susceptible and/or tolerant genotypes can be found for different species of the genus Malus (Isutsa and Merwin, 2000). Symptoms of ARD are expressed early after the first contact with ARD affected soil and include belowground a root browning and blackening, root tip necrosis, reduced number of root hairs and destroyed outer root cell layers 
(Caruso et al., 1989; Yim et al., 2013, GrunewaldtStöcker, unpublished data, Figure 2).

Aboveground plant parts show stunted or rosette growth (Caruso et al., 1989; Mazzola, 1998; Mazzola and Manici, 2012; Yim et al., 2013; Atucha et al., 2014; Emmett et al., 2014). These severe disorders result in a dramatically reduced plant biomass, fruit yield, as well as fruit size and flavor (Mazzola and Manici, 2012; Liu et al., 2014). The molecular and physiological reactions of apple plants to ARD soils resulting in these morphologically visible symptoms were only recently subject of first in-depth studies. The accumulation of phenolic compounds as antioxidants in roots and shoots under ARD, points to oxidative stress (reactive oxygen species) (Henfrey et al., 2015), and may be a consequence of plant damage from ARD induced plant secondary metabolites. Changes in patterns of phenolic compounds, like phloridzin and phloretin, benzoic acid and rutin (Börner, 1959; Hofmann et al., 2009; Yin et al., 2016, 2017; Leisso et al., 2017) could be the result or reason of ARD.
The exudation of these compounds may affect the complete soil microbiome or parts of it.

In addition, the abundance of antioxidative enzymes, such as peroxidases increased significantly four weeks after planting young apple rootstocks in ARD affected soil, whereas synthesis of these enzymes was lower in plants grown in gamma irradiated soil (Schmitz et al., unpublished results). Peroxidases oxidize hydrogen donors at the expense of peroxides. They are highly specific for hydrogen peroxide, but they accept a wide range of other hydrogen donors, including polyphenols. The higher activity of peroxidase could promote the oxidation of phenols into the antioxidative polyphenols in the roots (Ayyagari et al., 1996), which may lead to the visible browning and blackening symptoms as well as root tip necrosis.

After infection of roots of apple seedlings by Pythium ultimum, one of the potential causal agents of ARD, an upregulation of the expression of genes involved in the secondary metabolism occurred as well as differential expression of genes in plant
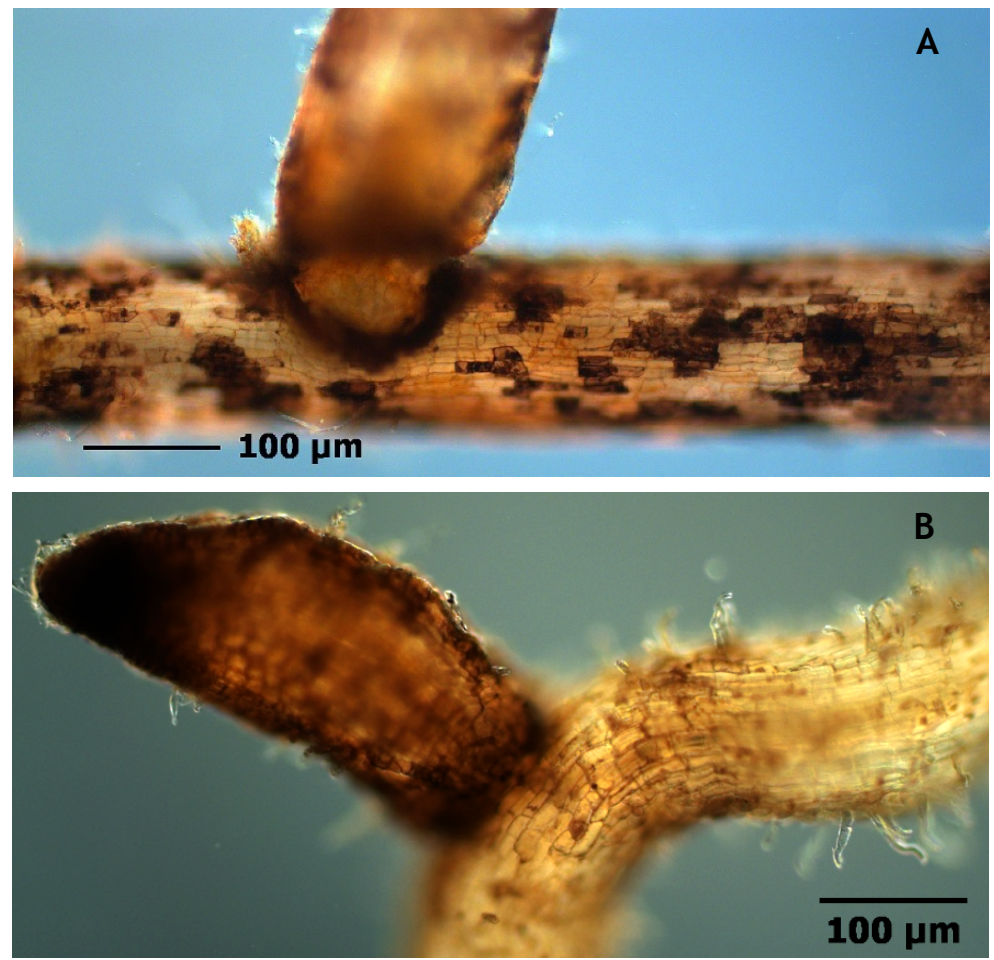

Figure 2. Cell necroses and blackening in the outer tissue layers of a branching fine root (A), and root tip necrosis (B) of apple rootstock Malus domestica M26, grown for two weeks in ARD affected soil. 
hormone metabolism (Shin et al., 2014, 2016; Zhu et al., 2014). Comparative transcriptomic studies of roots of the sensitive rootstock M26 grown either in ARD or gamma irradiated ARD soils revealed several differences in the expression of genes involved in stress responses (Weiß et al., 2017a, b). Further, when grown in ARD soil the plants reacted with an upregulation of expression of genes of the secondary metabolism, especially concerning the phytoalexin biosynthesis. Also, the corresponding phytoalexin products, i.e. biphenyls and dibenzofurans were detected in relatively high concentrations (Weiß et al., 2017b). A more detailed understanding of the molecular interplay of apple plants and their microbiome in healthy and ARD affected soils is urgently needed to define causes and consequences of ARD for plants and microbes (Manici et al., 2017).

\section{The role of spatial distribution of relevant parameters}

There are several observations indicating that the ARD causing agent, whatever it is, lacks mobility. Hoestra (1968) already reported in 1968, that ARD affects the apple tree in the first years of planting, thereafter the roots grow into deeper soil layers less impaired by ARD. He showed in growth experiments with soil extracted from different depths that ARD was mainly observed in $0-15$ and $15-30 \mathrm{~cm}$ soil depth. As also many soil properties and functions are heterogeneous under field conditions (Bogena et al., 2010; Gebbers and Adamchuk, 2010; Herbst et al., 2012), the patchiness of ARD related growth depression in the field as reported above, likewise hints in the same direction. Interestingly, ARD is induced more rapidly if the site is replanted frequently (nurseries) compared to sites permanently used for apple production. Frequent replanting is associated with more frequent mixing of soil due to uprooting and soil cultivation.

Restricted mobility of ARD causing agents, at least within the root system was also confirmed in a recent split-root experiment (Figure 3 ) of Lucas et al. (unpublished data). Apple plants grown in splitroot systems with different combinations of ARD soil, sterilized ARD soil or control soil (same site but never planted with apple) gained no reduction in shoot growth if half of the root system had access to soil not affected by ARD. The spatial separation is obviously crucial as simple dilution of the ARD soil by sterilized or control soil did not lead to comparable results (Hoestra, 1968; Jaffee et al., 1982; van Schoor et al., 2009; Tewoldemedhin et al., 2011; Spath et al., 2015). The split-root

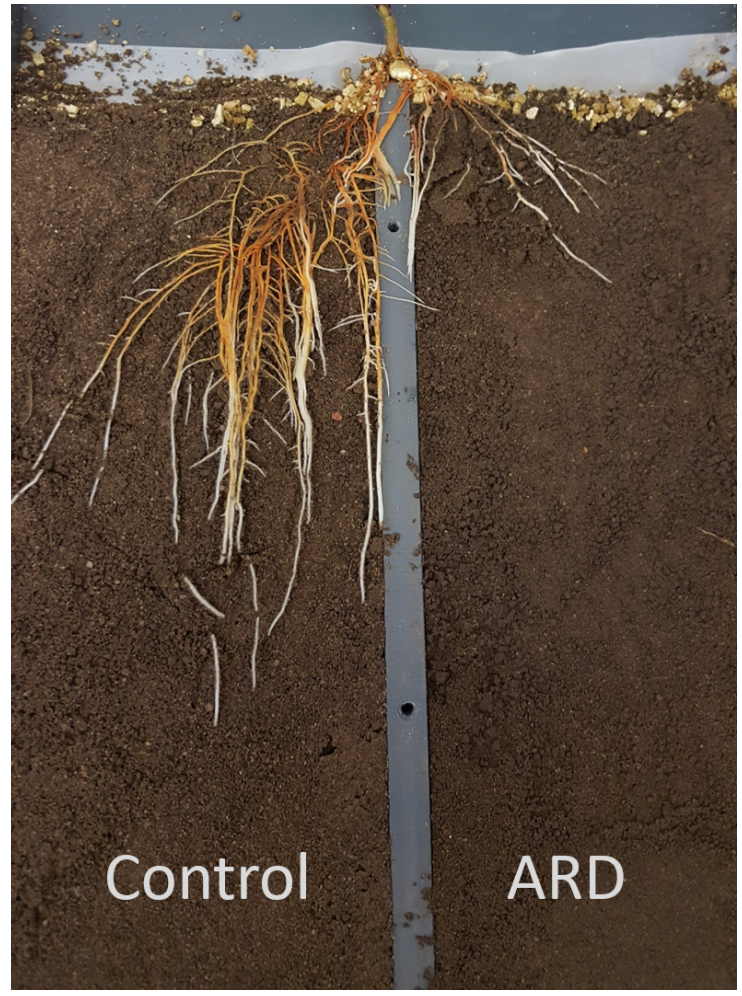

Figure 3. Root growth of Malus domestica M26 in a splitroot experiment. (Photo taken by Maik Lucas).

experiment of Lucas et al. (submitted) clearly showed that ARD is not systemic. Bacterial and fungal community composition in the rhizoplane and rhizosphere of the same plants differed significantly between the compartments containing ARD soil and those containing sterilized or control soil. However, some populations were only detected in the sterilized soil if the neighboring compartment contained ARD soil.

Further observations from our group (Zickenrott et al., unpublished data) indicate that apple plant roots avoid ARD soil patches, if given a choice. The mechanisms behind this are currently not known.

\section{Assessment of mitigation strategies for ARD}

Crop rotation is the first and oldest way to mitigate or circumvent ARD (Mazzola and Gu, 2001), but this is strongly limited or even not possible due to high investments in orchard infrastructure, for-instance in fences, hail nets, wells, pipes and more technology for irrigation. However, the main obstacle is the lack of areas for rotation in the production centers. Soil fumigation by chemicals is no longer possible in 
many countries due to the phase-out of the ecologically harmful fumigants. Biofumigation (Brown et al., 1991) using the incorporation of Brassicaceae plants or seed meal has been suggested as a counteraction and has shown first promising results (Mazzola et al., 2001, 2007, 2015; Yim et al., 2016, 2017), but cannot fully restore plant growth in most cases. The authors could prove that the application of Brassica napus seed meal amendments resulted in an increased abundance of Actinomycetes, e.g. Streptomycetes, and Pseudomonas in soil, bacterial groups being known for their high contribution to biocontrol of phytopathogens (Mazzola et al., 2007). The observed effects of applied $B$. napus seed meal were, however, variable and depended on the time of application, the concentration applied and the content of glucosinolates of the meal.

Further, several studies in the past have investigated the impact of fungicides like difenconazole or metalaxyl on the growth of apple trees in soils with replant disease symptoms (Mazzola, 1998). Although positive effects were obvious the issue of sustainability is questionable as a continuous application is needed. Because of the small specificity of the compounds other non-target populations like beneficial fungi might be affected with non-intended side effects.

Steam disinfection of soils is theoretically possible but too energy and time consuming and still fraught with technical problems, as demonstrated in current experiments in German nurseries. The costs of disinfecting soils with steam are 3-4 times higher than using chemicals (Nitt et al., 2015). Interestingly, the intercropping with Tagetes, conventionally used against nematodes, revealed increased growth of apple in two ARD soils, both in a bio-test as well as in field trials (Yim et al., 2017).

The idea to change more than the abundance of one microbial strain becomes more and more popular as it is well accepted that different microbial traits might contribute to overcome replant disease in soil, and that soil microbial diversity is strongly altered by replant disease (Sun et al., 2014; Berg et al., 2017). Already 25 years ago, Utkhede and Smith (1992) reported the promotion of apple tree growth and fruit production in a former ARD soil after inoculation with a strain of Bacillus subtillis, which showed biocontrol activities against various pathogens. The authors could prove that the inoculation procedure was more effective than a classical formalin fumigation, mainly, as it did not only increase shoot growth and the cross-sectional trunk area but resulted in higher yields, too. This concept of disease suppression via the inoculation of biocontrol microbes was further followed up, mainly as several authors could prove a high abundance of Rhizoctonia spp. from ARD soils (Mazzola, 1997). In 2007, the same author published data on the manipulation of rhizosphere bacterial communities to induce suppressive soils (Mazzola, 2007). Crop rotation, including wheat cultivation after apple growth, reduced the susceptibility of soils for ARD, and correspondingly an increase of fluorescent pseudomonads in the soil was observed (Mazzola et al., 2002). Therefore, it was suggested to use selected Pseudomonas strains of the species $P$. fluorescens or $P$. putida with biocontrol properties against Rhizoctonia for inoculation (Mazzola et al., 2002). These approaches seem to be promising, since the use of chemical substances can be avoided. However, it needs to be taken into account that microbe-based inoculation strategies need to consider on the one hand the potential risk of the inoculum for the environment. For example, $P$. putida has been recently classified into risk class II according to the German biosafety level, as several severe cases of infections of humans with $P$. putida have been reported (Carpenter et al., 2008). On the other hand, inoculation-based approaches often do not result in the expected outcome as the inoculated microbes did not establish well in soil and were outcompeted by the autochthonous microflora in the soil. Here developments using specific carrier materials for the inoculum have been proven to be successful, which give inocula a protected initial niche for performance (van Elsas and Heijnen, 1990). Furthermore, an improved understanding of the ecology of inoculants is required for more reliable and efficient use (Berg et al., 2017).

Numerous experiments, in which treatments with Trichoderma harzianum (Wrede, 2015), cyanamid, stone dust and fertilizers amended with organic compounds such as humus, alkaline substances and seaweed were tested, were not or not sufficiently effective. Also, by incorporating spent mushroom compost, a composted substrate from mushroom production, into ARD soil, an increase of microbial activity was achieved leading to a significant increase in shoot growth, an effect being comparable to that of pasteurization (Manici, 2015; Franke-Whittle et al., 2018). More research is necessary to support or reject the hypothesis that many of these compounds were ineffective in harming soil pathogens, because they might have 
persisted in microhabitats different from those reached by the amendments.

The influence of important compounds exuded or released from roots ploughed into soil must be evaluated. In this respect, also carbon sourcedependent effects of anaerobic soil disinfestation might be discussed (Hewavitharana and Mazzola, 2016).

Arbuscular mycorrhizal fungi (AMF) are essential endophytic players in the microbial network in the rhizosphere as well as in plant root systems. Besides the often-cited promotion of $P$ acquisition, the mycorrhizal host plants have manifold advantages for their survival and productivity (Finlay, 2004; Smith and Read, 2008; Smith and Smith, 2012). Thus, a positive contribution of AMF to healthy apple growth and productivity is the normal case. The selection and application of AMF isolates for a recovery from ARD has been considered a possible strategy, but seems to be a rather difficult aim. Since long, this approach gained often less successful results in other instances of disease control, especially in field trials (Schönbeck et al., 1994; Linderman, 2000; Whipps, 2004). However, the AM symbiosis can lead to striking positive effects in plant productivity when damages of abiotic stress, e.g. drought (Pinior et al., 2005) or of infections by soil borne pathogens (GrunewaldtStöcker and von Alten, 2003; Whipps, 2004) and of nematodes (Calvet et al., 2001) were diminished. Regarding ARD, Čatská (1994) described a promising significant increase in productivity of apple plants (shoot and root biomass) due to Glomus fasciculatum, applied to ARD soil of two diverse soil types. Moreover, this mycorrhizal effect occurred together with an altered composition of the rhizosphere microbiome. Mehta and Bharat (2013) confirmed in tests with several AM fungi the specific success of a Glomus fasciculatum strain to overcome apple growth depression in ARD soil.

To apply selected effective AMF for an ARD therapy at a large scale in nurseries or field sites, the production of AMF inoculum, the formulation, shelf life and commercial supply are yet difficult (AzcónAguilar and Barea, 1997; Whipps, 2004). Nevertheless, the strategy to exploit naturally occurring or introduced AMF with a potential to alleviate abiotic stress and to control soil borne pathogens in combination with other biological agents or measurements against ARD seems attractive. AMF together with fine root endophytes (Glomus tenue, Orchard et al., 2017), are essential in the microbiome network and need attention, promotion and protection by all cultural practices. The recently widened molecular methods (e.g. realtime PCR quantification of AMF, Alkan et al., 2004, Voříšková et al., 2017; DNA based sequencing for identification and diversity studies of AMF, Vasar et al., 2017) can help to determine fungal communities with positive effects on apple plants. Also, AMF isolates harboring mycoviruses (Ikeda et al., 2012) or endobacteria (Venice et al., 2017) are of interest with regard to their influence on the symbiotic performance of AMF in ARD soil as well as in biocontrol strategies.

Besides modulating the soil microbiome, several recent strategies include the improvement of plant tolerance towards replant disease. Breeding of less susceptible rootstocks seems feasible as tolerant genotypes are available in Malus germplasm (e.g. Isutsa and Merwin, 2000; St. Laurent et al., 2010; Robinson et al., 2012; Volk et al., 2013). In addition, an improved strategy for defense responses of plant roots by modulating cellular signals such as the oscillation of $\mathrm{Ca}^{2+}$ concentration, reactive oxygen species burst or protein kinase activity (Emmett et al., 2014) is under debate.

Finally, more work needs to be done to assess the socio-economic benefits of such approaches.

\section{Conclusions}

Despite increasing data on ARD, combined efforts of plant scientists, ecologists, microbiologists, soil scientists as well as socio-economists and growers are needed to fully understand and overcome ARD. The German consortium BonaRes ORDIAmur (Overcoming Replant Disease by an Integrated Approach; www.ordiamur.de) aims at finding indicators for infected soil, to restore its functional biodiversity, to identify and use genetic factors controlling ARD in apple and to optimize the composition of microbial communities to promote apple growth in ARD soil (Figure 4). Two important considerations for future research in ARD have to be taken into account: Firstly, a proper comparison to healthy or virgin soil is difficult, since even small spatial distances to sites where healthy soil is taken might involve very drastic changes in soil physical, chemical and biological properties. Moreover, the vegetation of the control site will also influence the (micro)biome of the soils. On the other hand, disinfected soil can neither be considered a proper control soil. Secondly, future studies should emphasize the soil sampling and distinguish bulk soil, rhizosphere and rhizoplane, as well as define 


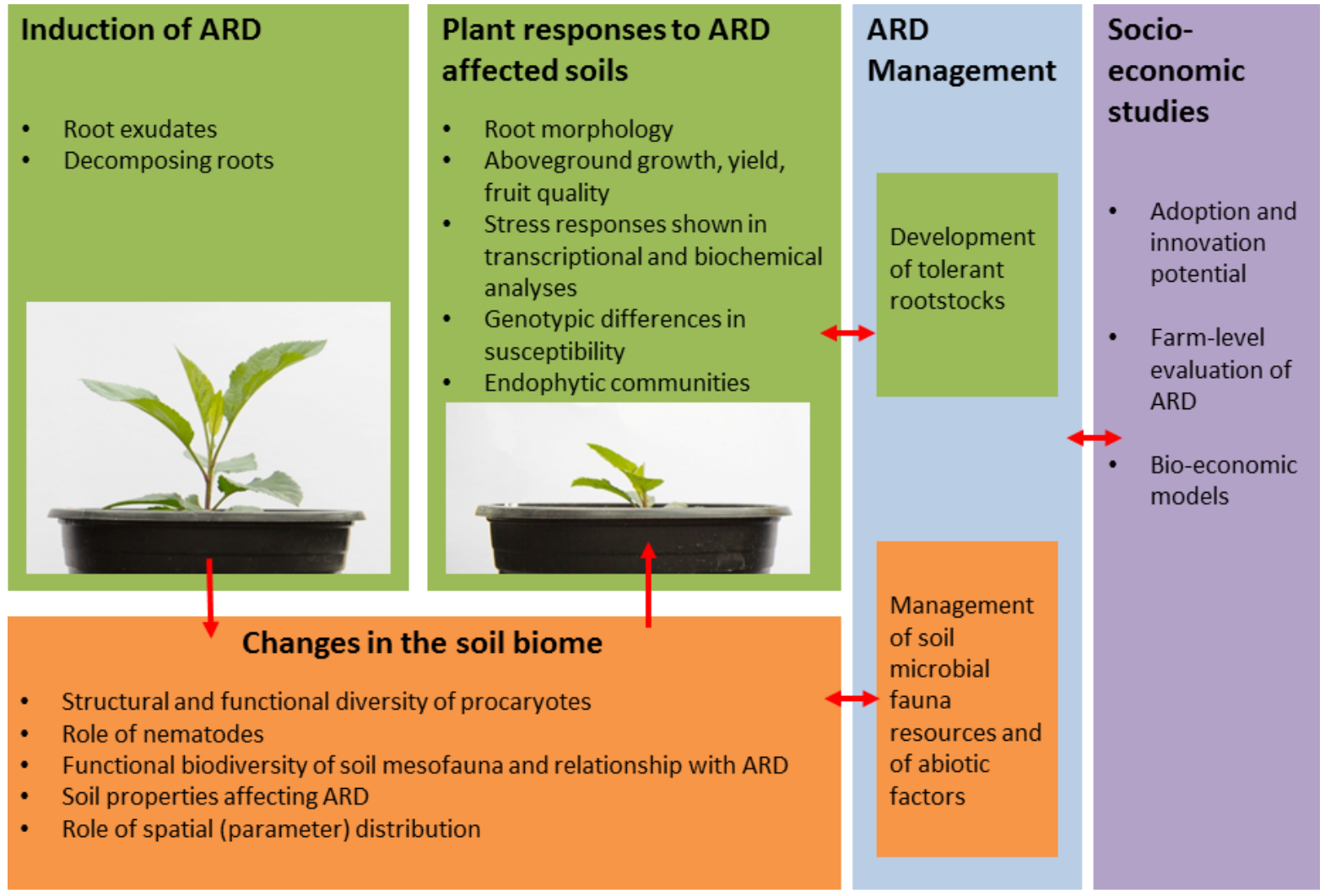

Figure 4. The understanding and management of apple replant disease (ARD) goes beyond disciplinary expertise - The ORDIAmur concept: Complex interactions of plant driven metabolites and soil-borne (micro)biome changes induce ARD. Future studies will have to focus on managing techniques including manipulation of plant attributes and soil microbial communities accompanied by socio-economic studies.

the root order and degree of damage. For both aspects, reproducible and internationally accepted definitions would be helpful.

\section{Acknowledgements}

The authors gratefully acknowledge funding of the project ORDIAmur by the German Federal Ministry of Research and Education within the frame of the program BonaRes (grant no. 031B0025).

\section{References}

Adam, M., Westphal, A., Hallmann, J., and Heuer, H. (2014). Invertebrate microbiology: Specific microbial attachment to root knot nematodes in suppressive soil. Environ. Microbiol. 80, 2679-2686. https://doi:10.1128/AEM.03905-13

Alkan, N., Gadkar, V., Coburn, J., Yarden, O., and Kapulnik, Y. (2004). Quantification of the arbuscular mycorrhizal fungus Glomus intraradices in host tissue using real-time polymerase chain reaction. New Phytol. 161, 877-885. doi:10.1111/j.1469-8137.2003.00975.x
Amelung, W., Brodowski, S., Sandhage-Hofmann, A., and Bol, R. (2008). Combining biomarker with stable isotope analyses for assessing the transformation and turnover of soil organic matter. Adv. Agron. 100, 155-250. https://doi.org/10.1016/ S0065-2113(08)00606-8

Atucha, A., Emmett, B., and Bauerle, T.L. (2014). Growth rate of fine root systems influences rootstock tolerance to replant disease. Plant Soil 376, 337-346. https://doi.org/10.1007/ s11104-013-1977-5

Ayyagari, J., Akkara, A., and Kaplan, D.L. (1996). Enzyme-mediated polymerization reactions: peroxidase-catalyzed polyphenol synthesis. Acta Polym. 47, 193-203. https://doi.org/10.1002/actp. 1996.010470501

Azcón-Aguilar, C., and Barea, J. M. (1997). Applying mycorrhiza biotechnology to horticulture: significance and potentials. Sci. Hortic. 68, 1-24. https://doi.org/10.1016/S0304-4238(96)00954-5

Berg, G., Köberl, M, Rybakova, D., Müller, H., Grosch, R., and Smalla, K. (2017). Plant microbial 
diversity is suggested as the key to future biocontrol and health trends. FEMS Microbiology Ecology 93, fix050. https://doi:10.1093/femsec/ fix050

Böllmann, J., Elmer, M., Woellecke, J., Raidl, S., and Huettl, R.F. (2010). Defensive strategies of soil fungi to prevent grazing by Folsomia candida (Collembola). Pedobiologia 53, 107-114. https:// doi.org/10.1016/j.pedobi.2009.06.003

Bogena, H.R., Herbst, M., Huisman, J.A., Rosenbaum, U., Weuthen, A., and Vereecken, $H$. (2010). Potential of wireless sensor networks for measuring soil water content variability. Vadose Zone J. 9, 1002-1013. https://doi.org/10.2136/ vzj2009.0173

Börner, H. (1959). The apple replant problem. I. The excretion of phloridzin from apple root residues. Contributions of the Boyce Thompson Institute of Plant Research 20, 39-56.

Brown, P.D., Morra, M.J., McCafferey, J.P., Auld, D.L., and Williams, L. (1991). Allelochemicals produced during glucosinolate degradation in soil. J. Chem. Ecol. 17, 2021-2034. https://doi.org/ 10.1007/BF00992585

Calvet, C., Pinochet, J., Hernández-Dorrego, A., Estáun, V., and Camprubi, A. (2001). Field microplot performance of the peach-almond hybrid GF-677 after inoculation with arbuscular mycorrhizal fungi in a replant soil infested with root-knot nematodes. Mycorrhiza 10, 295-300. https://doi.org/10.1007/PL00009998

Caputo, F., Nicoletti, F., De Luca Picione, F., and Manici, L.M. (2015). Rhizospheric changes of fungal and bacterial communities in relation to soil health of multi-generation apple orchards. Biol. Control 88, 8-17. https://doi.org/10.1016/ j.biocontrol.2015.04.019

Carpenter, R.J., Hartzell, J.D., Forsberg, J.A., Babel, B.S., and Ganesan, A. (2008). Pseudomonas putida war wound infection in a US Marine: a case report and review of the literature. J. Infection 56(4), 234-240. https://doi.org/ 10.1016/j.jinf.2008.01.004

Caruso, F.L., Neubauer, B.F., and Begin, M.D. (1989). A histological study of apple roots affected by replant disease. Can. J. Bot. 67, 742-749. https://doi.org/10.1139/b89-100

Čatská, V. (1994). Interrelationships between vesicular-arbuscular mycorrhiza and rhizosphere microflora in apple replant disease. Biol. Plantarum 36, 99-104. https://doi.org/10.1007/ BF02921276

Chelinho, S., Domene, X., Andrés, P., Natal-da-Luz, T., Norte, C., Rufino, C., Lopes, I., Cachada, A., Espindola, E., Ribeiro, R., Costa-Duarte, A., and
Sousa, J.P. (2014). Soil microarthropod community testing: A new approach to increase the ecological relevance of effect data for pesticide risk assessment. Applied Soil Ecol. 83, 200-209. https://doi.org/10.1016/j.apsoil. 2013.06.009

Ciglasch, H., Busche, J., Amelung, W., Totrakool, S., and Kaupenjohann, M. (2008). Field aging of insecticides after repeated application to a northern Thailand ultisol. J. Agr. Food Chem. 56, 9555-9562. https://doi.org/10.1021/jf801545h

Covey Jr, R.P., Benson, N.R., and Haglund, W.A. (1979). Effect of soil fumigation on the apple replant disease in Washington [USA]. Phytopathology 69, 684-686.

Derrien, D., Marol, C., Balabane, M., and Balesdent, J. (2006). The turnover of carbohydrate content in a cultivated soil estimated by $13 \mathrm{C}$ natural abundances. Eur. J. Soil Sci. 57(4), 547-557. https://doi.org/10.1111/j.1365-2389.2006.00811.x

Djigal, D., Brauman, A., Diop, T.A., Chotte, J.L., and Villenave, C. (2004). Influence of bacterial-feeding nematodes (Cephalobidae) on soil microbial communities during maize growth. Soil Biol. Biochem. 36, 323-331. https://doi.org/10.1016/ j.soilbio.2003.10.007

Dunn, R.A., and Mai, W.F. (1972). Root diseases of fruit trees in New York State. V. Growth of apple trees in response to preplant treatment with nematicides and a broad-spectrum fumigant. Plant Dis. Rep. 56, 577-580.

Elhady, A., Giné, A., Topalovic, O., Jacquiod, S., Sørensen, S.J., Sorribas, F.J., and Heuer, H. (2017). Microbiomes associated with infective stages of root-knot and lesion nematodes in soil. Plos One 12, e0177145. https://doi.org/10.1371/ journal.pone. 0177145

Emmett, B., Nelson, E.B., Kessler, A., and Bauerle, T.L. (2014). Fine-root system development and susceptibility to pathogen colonization. Planta 239, 325-340. https://doi.org/10.1007/ s00425-013-1989-7

Fan, H., Zhao, Z., Liu, H., Guodong, Z.X., and Zhang, Z. (2010). Changes of soil nutrition in root zone and their effects on growth of the replanted apple. Yuanyi Xuebao 35, 1727-1734 (in Chinese; cited from abstract).

Fazio, G., Kviklys, D., Grusak, M.A., and Robinson, T. (2012). Soil pH, soil type and replant disease affect growth and nutrient absorption in apple rootstocks. New York State Fruit Quarterly 20, 22-28.

Finlay, R.D. (2004). Mycorrhizal fungi and their multifunctional roles. Mycologist 18, 91-96. https:// doi.org/10.1017/S0269-915X(04)00205-8 
Frampton, G.K. (2002). Long-term impacts of an organophosphate-based regime of pesticides on field and field-edge Collembola communities. Pest Manag. Sci. 58, 991-1001. https://doi.org/10.1002/ ps. 580

Franke-Whittle, I.H., Manici, L.M., Insam, H., and Stres, B. (2015). Rhizosphere bacteria and fungi associated with plant growth in soils of three replanted apple orchards. Plant Soil 395, 317-333. https://doi.org/10.1007/s11104-015-2562-x

Franke-Whittle, I.H., Fernández-Delgado Juárez, M., Insam, H., Schweizer, S., Naef, A., Topp, A.R., Kelderer, M., Rühmer, T., Baab, G., Henfrey, J., and Manici, L.M. (2018): Performance evaluation of locally available composts to reduce replant disease in apple orchards of central Europe. Renewable Agriculture and Food Systems. https:// doi.org/10.1017/S1742170518000091

Freckman, D.W. (1988). Bacterivorous nematodes and organic-matter decomposition. Agr. Ecosyst. Environ. 24, 195-217. https://doi.org/ 10.1016/0167-8809(88)90066-7

Gebbers, R., and Adamchuk, V.I. (2010). Precision agriculture and food security. Science 327 , 828-831. https://doi.org/10.1126/science.1183899

Gebremikael, M.T., Steel, H., Buchan, D., Bert, W., and de Neve, S. (2016). Nematodes enhance plant growth and nutrient uptake under $\mathrm{C}$ and $\mathrm{N}$ rich conditions. Sci. Rep.-UK 6, 32862. https:// doi.org/10.1038/srep32862

Glisczynski, F., Sandhage-Hofmann, A., Amelung, W., and Pude, R. (2016). Biochar-compost substrates do not promote growth and fruit quality of a replanted German apple orchard with fertile Haplic Luvisol soils. Sci. Hortic. 213, 110-114. https://doi.org/10.1016/j.scienta.2016.10.023

Grunewaldt-Stöcker, G., and von Alten, H. (2003). Plant health effects of Acremonium root endophytes compared to those of arbuscular mycorrhiza. In Roots: The dynamic interface between plants and the earth, J. Abe, ed. (Dordrecht, Netherlands: Kluwer Academic Publishers), pp. 445-454. https://doi.org/ 10.1007/978-94-017-2923-9_44

Hai-Feng, X., Gen, L.I., Da-Ming, L.I., Feng, H.U., and Hui-Xin, L.I. (2014). Effect of different bacterial-feeding nematode species on soil bacterial numbers, activity, and community composition. Pedosphere 24, 116-124. https:// doi.org/10.1016/S1002-0160(13)60086-7

Hatzinger, P.B., and Alexander, M. (1995). Effect of aging of chemicals in soils on their biodegradability and extractability. Environ. Sci. Technol. 29, 537-545. https://doi.org/10.1021/ es00002a033
Henfrey, J.L., Baab, G., and Schmitz, M. (2015). Physiological stress responses in apple under replant conditions. Sci. Hortic.-Amsterdam 194, 111-117. https://doi.org/10.1016/j.scienta.2015.07.034

Herbst, M., Bornemann, L., Graf, A., Welp, G., Vereecken, H., and Amelung, W. (2012). A geostatistical approach to the field-scale pattern of heterotrophic soil $\mathrm{CO}_{2}$ emission using covariates. Biogeochem. 111, 377-392. https:// doi.org/10.1007/s10533-011-9661-4

Hewavitharana, SS., and Mazzola, M. (2016). Carbon Source-Dependent Effects of Anaerobic Soil Disinfestation on Soil Microbiome and Suppression of Rhizoctonia solani AG-5 and Pratylenchus penetrans. Phytopathology 106, 1015-1028. https://doi.org/10.1094/ PHYTO-12-15-0329-R

Hoestra, H. (1968). Replant diseases of apple in The Netherlands. Dissertation Landbouwhogesch, Wageningen. https://edepot.wur.nl/285366

Hoestra, H., and Oostenbrink, M. (1962). Nematodes in relation to plant growth. IV. Pratylenchus penetrans (Cobb) on orchard trees. Neth. J. Agr. Sci. 10, 286-296.

Hofmann, A., Wittenmayer, L., Arnold, G., Schieber, A., and Merbach, W. (2009). Root exudation of phloridzin by apple seedlings (Malus $x$ domestica Borkh.) with symptoms of apple replant disease. J. Appl. Bot. Food Qual. 82, 193-198.

Hopkin, S.P. (1997). Biology of the springtails. (Insecta: Collembola). (Oxford, New York, USA: Oxford University Press). http://www.loc.gov/ catdir/enhancements/fy0605/96034592-d.html

Ikeda, Y., Shimura, H., Kitahara, R., Masuta, C., and Ezawa, T. (2012). A novel virus-like doublestranded RNA in an obligate biotroph arbuscular mycorrhizal fungus: A hidden player in mycorrhizal symbiosis. MPMI 25, 1005-1012. https://doi.org/ 10.1094/MPMI-11-11-0288

Innocenti, G., Ganassi, S., Montanari, M., Branzanti, M.B., and Sabatini, M.A. (2009). Response of plant growth to Collembola, arbuscular mycorrhizal and plant pathogenic fungi interactions. B. Insectol. 62, 191-195.

Innocenti, G., Montanari, M., Ganassi, S., and Sabatini, M.A. (2011). Does substrate water content influence the effect of Collembolapathogenic fungus interaction on plant health? A mesocosm study. B. Insectol. 64, 73-76.

Isutsa, D.K., and Merwin, I.A. (2000). Malus germplasm varies in resistance or tolerance to apple replant disease in a mixture of New York orchard soils. Hortscience 35(2), 262-268.

Jaffee, B.A., Abawi, G.S., and Mai, W.F. (1982). Role of soil microflora and Pratylenchus 
penetrans in an apple replant disease. Phytopathology 72, 247-251. https://doi.org/ 10.1094/Phyto-72-247

Jonkers, H., Hoestra, H., Borsboom, O., and Power, A. (1980). Soil $\mathrm{pH}$ in fruit trees in relation to specific apple replant disorder (SARD). II: The first five years at the Wageningen research plot. Sci. Hortic.-Amsterdam 13, 149-154. https:// doi.org/10.1016/0304-4238(80)90079-5

Kanters, C., Anderson, I.C., and Johnson, D. (2015). Chewing up the wood-wide web: Selective grazing on ectomycorrhizal fungi by Collembola. Forests 6, 2560-2570. http://doi.org/10.3390/ f6082560

Klaus, H. (1939). Das Problem der Bodenmüdigkeit unter Berücksichtigung des Obstbaus. Landw. Jahrb. 89, 413-459.

Kögel-Knabner, I., and Amelung, W. (2014). Dynamics, chemistry, and preservation of organic matter in soils. In Treatise on Geochemistry (Second Edition), H.D. Holland and K.K. Turekian, eds. (Oxford, UK: Elsevier Ltd), pp. 157-215.

Kuzyakov, Y., and Larionova, A.A. (2005). Root and rhizomicrobial respiration: A review of approaches to estimate respiration by autotrophic and heterotrophic organisms in soil. J. Plant Nutr. Soil Sci. 168, 503-520. http://doi.org/10.1002/jpln. 200421703

Larsen, T., Schjonning, P., and Axelsen, J. (2004). The impact of soil compaction on euedaphic Collembola. Appl. Soil Ecol. 26, 273-281. https:// doi.org/10.1016/j.apsoil.2003.12.006

Lartey, R.T., Curl, E.A., and Peterson, C.M. (1994). Interactions of mycophygous Collembola and biological control fungi in the suppression of Rhizoctonia solani. Soil Biol. Biochem. 26, 81-88. https://doi.org/10.1016/0038-0717(94)90198-8

Leisso, R., Rudell, D., and Mazzola, M. (2017). Metabolic composition of apple rootstock rhizodeposits differs in a genotype-specific manner and affects growth of subsequent plantings. Soil Biol. Biochem. 113, 201-214. https://doi.org/10.1016/j.soilbio.2017.06.011

Linderman, R.G. (2000). Effects of mycorrhizas on plant tolerance to diseases. In Arbuscular mycorrhizas: Physiology and Function, Y. Kapulnik and D.D. Douds Jr, eds. (Dordrecht, Netherlands: Kluwer Academic Publishers), pp. 345-365. https://doi.org/10.1007/978-94-017-0776-3_15

Liu, E.T., Wang, G.S., Li, Y.Y., Shen, X., Chen, X.S., Song, F.H., Wu, S.J., Chen, Q., and Mao, Z.Q. (2014). Replanting affects the tree growth and fruit quality of Gala apple. J. Integr. Agr. 13, 1699-1706. https://doi.org/10.1016/ S2095-3119(13)60620-6
Lueking, A.D., Huang, W., Soderstrom-Schwarz, S., and Kim Jr, M.S. (2000). Relationship of soil organic matter characteristics to organic contaminant sequestration and bioavailability. J. Environ. Qual. 29, 317-323. https://doi.org/ 10.2134/jeq2000.00472425002900010040x

Mai, W.F., and Abawi, G.S. (1978). Determining the cause and extent of apple, cherry, and pear replant diseases under controlled conditions. Phytopathology 68, 1540-1544. https://doi.org/ 10.1094/Phyto-68-1540

Mai, W.F., and Abawi, G.S. (1981). Controlling replant disease of stone fruits in northeastern United States by preplant fumigation. Plant Dis. 65, 859-864. https://doi.org/10.1094/PD-65-859

Mai, W.F., Merwin, I.A., and Abawi, G.S. (1994). Diagnosis, etiology and management of replant disorders in New York cherry and apple orchards. Acta Hortic. 363, 33-42. https://doi.org/10.17660/ ActaHortic.1994.363.5

Manici, L (2015). Bio-Incrop CORE organic Innovative cropping technique to increase soil health in organic fruit tree crops. EU project 2012 - 2014. Project Leader: Manici, L.M. http:// orgprints.org/29112/1/BIO-INCROP_COII_final_ report_web_version.pdf

Manici, L.M., Caputo, F., and Saccà, M.L. (2017). Secondary metabolites released into the rhizosphere by Fusarium oxysporum and Fusarium spp. as underestimated component of nonspecific replant disease. Plant Soil. https:// doi.org/10.1007/s11104-016-3152-2

Manici, L.M., Kelderer, M., Franke-Whittle, I.H., Rühmer, T., Baab, G., Nicoletti, F., Caputo, F., Topp, A., Insam, H., and Naef A. (2013). Relationship between root-endophytic microbial communities and replant disease in specialized apple growing areas in Europe. Appl. Soil Ecol. 72, 207-214. https://doi.org/10.1016/j.apsoil. 2013.07.011

Manici, L. M., Kelderer, M., Caputo, F., Saccà, M. L., Nicoletti, F., Topp, A. R., and Mazzola, M. (2018). Involvement of Dactylonectria and Ilyonectria spp. in tree decline affecting multi-generation apple orchards. Plant and Soil 425: 217-230. https:// doi.org/10.1007/s11104-018-3571-3

Mazzola, M. (1997). Identification and pathogenicity of Rhizoctonia spp. isolated from apple roots and orchard soils. Phytopathology 87(6), 582-587. https://doi.org/10.1094/PHYTO.1997.87.6.582

Mazzola, M. (1998). Elucidation of the microbial complex having a causal role in the development of apple replant disease in Washington. Phytopathology 88, 930-938. https://doi.org/ 10.1094/PHYTO.1998.88.9.930 
Mazzola, M. (2007). Manipulation of rhizosphere bacterial communities to induce suppressive soils. J. Nematol. 39(3), 213-220.

Mazzola, M., Brown, J., Izzo, A.D., and Cohen, M.F. (2007). Mechanism of action and efficacy of seed meal-induced pathogen suppression differ in a Brassicaceae species and time dependent manner. Phytopathology 97, 454-460. https:// doi.org/10.1094/PHYTO-97-4-0454

Mazzola, M., Granatstein, D.M., Elfving, D.C., and Mullinix, K. (2001). Suppression of specific apple root pathogens by Brassica napus seed meal amendment regardless of glucosinolate content. Phytopathology 91, 673-79. https://doi.org/ 10.1094/PHYTO.2001.91.7.673

Mazzola, M., Granatstein, D.M., Elfving, D.C., Mullinix, K., and Gu, Y.H. (2002) Cultural management of microbial community structure to enhance growth of apple in replant soils. Phytopathology 92(12), 1363-1366. https:// doi.org/10.1094/PHYTO.2002.92.12.1363

Mazzola, M., and Gu, Y.H. (2000). Impact of wheat cultivation on microbial communities from replant soils and apple growth in greenhouse trials. Phytopathology 90(2), 114-119. https://doi.org/ 10.1094/PHYTO.2000.90.2.114

Mazzola, M., Hewavitharana, S.S., and Strauss, S.L. (2015). Brassica seed meal soil amendments transform the rhizosphere microbiome and improve apple production through resistance to pathogen reinfestation. Phytopathology 105, 460-469. https://doi.org/10.1094/PHYTO-09-14-0247-R

Mazzola, M., and Manici, L.M. (2012). Apple replant disease: Role of microbial ecology in cause and control. Annu. Rev. Phytopathol. 50, 45-65. https:// doi.org/10.1146/annurev-phyto-081211-173005

Mazzola, M., and Mullinix, K. (2005). Comparative field efficacy of management strategies containing Brassica napus seed meal or green manure for the control of apple replant disease. Plant Dis. 89, 1207-1213. https://doi.org/10.1094/PD-89-1207

Mehta, P., and Bharat, N.K. (2013). Effect of indigenous arbuscular- mycorrhiza (Glomus spp) on apple (Malus domestica) seedlings grown in replant diseased soil. Ind. J. Agr. Sci. 83, 1173-1178.

Nicola, L., Turco, E., Albanese, D., Donati, C., Thalheimer, M., Pindo, M., Insam, H., Cavalieri, D., and Pertot, I. (2017). Fumigation with dazomet modifies soil microbiota in apple orchards affected by replant disease. Appl. Soil Ecol. 113, 71-79. https://doi.org/10.1016/j.apsoil.2017.02.002

Nitt, H., Yim, B., Wrede, A., Hanschen, F., Loesing, H., Schreiner, M., Smalla, K., Grunewaldt, J., and Winkelmann, T. (2015). Bodenmüdigkeit und
Lösungen (Baumschulen) Gesunder Boden Gesunder Gartenbau. Kongress zum Jahr des Bodens, Tagungsband, 16. November 2015, Berlin. https://www.bmel.de/SharedDocs/ Downloads/Landwirtschaft/JahrdesBodens/ TagungsbandKongressJahrdesBodens.pdf? blob=publicationFile

Oades, J.M. (1988). The retention of organic matter in soils. Biogeochem. 5, 35-70. https://doi.org/ 10.1007/BF02180317

Orchard, S., Standish, R.J., Dickie, I.A., Renton, M., Walker, C., Moot, D. and Ryan, M.H. (2017). Fine root endophytes under scrutiny: a review of the literature on arbuscule-producing fungi recently suggested to belong to the Mucoromycotina. Mycorrhiza 27, 619-638. https://doi.org/10.1007/ s00572-017-0782-z

Otto, G., Winkler, H., and Szabo K. (1994). Proof of actinomycetes in rootlets of species of Rosaceae from a SARD soil - a contribution to the specificity of replant diseases. Acta Hortic. 363, 43-48. https://doi.org/10.17660/ActaHortic.1994.363.6

Peruzzi, E., Franke-Whittle, I.H., Kelderer, M., Ciavatta, C., and Insam, H. (2017). Microbial indication of soil health in apple orchards affected by replant disease. Appl. Soil Ecol. 119, 115-127. https://doi.org/10.1016/j.apsoil.2017.06.003

Pinior, A., Grunewaldt-Stöcker, G., von Alten, H., and Strasser, R.J. (2005). Mycorrhizal impact on drought stress tolerance of rose plants probed by chlorophyll a fluorescence, proline content and visual scoring. Mycorrhiza 15, 596-605. https:// doi.org/10.1007/s00572-005-0001-1

Robinson, T., Autio, W., Clements, J., Cowgill, W., Embree, C., Gonzalez, V., Hoying, S., Kushad, M., Parker, M., Parra, R., and Schupp, J. (2012). Rootstock tolerance to apple replant disease for improved sustainability of apple production. Acta Hortic. 940, 521-528.

Rosendahl, I., Siemens, J., Kindler, R., Groeneweg, J., Zimmermann, J., Czerwinski, S., Lamshöft, M., Laabs, V., Wilke, B.M., Vereecken, H., and Amelung, W. (2012). Persistence of the fluoroquinolone antibiotic difloxacin in soil and lacking effects on N-turnover. J. Environ. Qual. 41, 1275-1283. https://doi.org/10.2134/jeq2011.0459

Roy, S., Bano, R., Saxena, P., and Bhatt, R.K. (2014). Land uses and its impact on community structure of soil collembola. Range Manag. Agrofor. 35, 27-31.

Rumberger, A., Merwin, I.A., and Thies, J.E. (2007). Microbial community development in the rhizosphere of apple trees at a replant disease site. Soil Biol. Biochem. 39, 1645-1654. https:// doi.org/10.1016/j.soilbio.2007.01.023 
Sabatini, M.A., and Innocenti, G. (2000). Functional relationships between Collembola and plant pathogenic fungi of agricultural soils. Pedobiologia 44 , 467 -475. https://doi.org/10.1078/ S0031-4056(04)70064-5

Sabatini, M.A., and Innocenti, G. (2001). Effects of Collembola on plant-pathogenic fungus interactions in simple experimental systems. Biol. Fert. Soils 33, 62-66. https://doi.org/10.1007/ s003740000290

San Miguel, A., Raveton, M., Lemperiere, G., and Ravanel, P. (2008). Phenylpyrazoles impact on Folsomia candida (Collembola). Soil Biol. Biochem. 40, 2351-2357. https://doi.org/10.1016/ j.soilbio.2008.05.014

Savory, B.M. (1966). Specific replant diseases causing root necrosis and growth depression in perennial fruit and plantation crops. Research Review No. 1. Commonwealth Bureau of Horticulture and Plantation Crops, East Malling, Maidstone, Kent, England.

Schönbeck, F., Grunewaldt-Stöcker, G., and von Alten, H. (1994). Mycorrhizae. In Epidemiology and management of root diseases, C.L. Campbell and D.M. Benson, eds. (Berlin, Heidelberg, New York: Springer Verlag), pp. 65-81.

Schrader, S., Langmaack, M., and Helming, K. (1997). Impact of Collembola and enchytraeidae on soil surface roughness and properties. Biol. Fert. Soils 25, 396-400. https://doi.org/10.1007/ s003740050331

Sewell, G.W., Preece, D.A., and Elsey, R.F. (1988). Apple replant disease: the influence of soil phosphorus and other factors on the growth responses of apple seedlings to soil fumigation with chloropicrin. Ann. Appl. Biol. 113, 605-615. https://doi.org/10.1111/j. 1744-7348.1988.tb03338.x

Shin, S., Lv, J., Fazio, G., Mazzola, M., and Zhu, Y. (2014). Transcriptional regulation of ethylene and jasmonate mediated defense response in apple (Malus domestica) root during Pythium ultimum infection. Horticulture Research 1, 14053. https:// doi.org/10.1038/hortres.2014.53

Shin, S., Zheng, P., Fazio, G., Mazzola, M., Main, D., and Zhu, Y. (2016). Transcriptome changes specifically associated with apple (Malus domestica) root defense response during Pythium ultimum infection. Physiol. Mol. Plant P. 94, 16-26. https://doi.org/10.1016/j.pmpp.2016.03.003

Smith, S.E., and Read, D.J. (2008). Mycorrhizal symbiosis (Third Edition, New York, USA: Academic Press).

Smith, S.E., and Smith, F. (2012). Fresh perspectives on the roles of arbuscular mycorrhizal fungi in plant nutrition and growth. Mycologia 104, 1-13. https://doi.org/ 10.3852/11-229

Spath, M., Insam, H., Peintner, U., Kelderer, M., Kuhnert-Finkernagel, R., and Franke-Whittle I.H. (2015). Linking soil biotic and abiotic factors to apple replant disease: a greenhouse approach. J. Phytopathol. 163, 287-299. https://doi.org/ 10.1111/jph.12318

Spethmann, W., and Otto, G. (2003). Replant problems and soil sickness. In Encyclopedia of Rose Science, A.V. Roberts, T. Debener, S. Gudin, eds. (Oxford, UK: Elsevier LTD), pp. 169-180.

Steinaker, D.F., and Wilson, S.D. (2008). Scale and density dependent relationships among roots, mycorrhizal fungi and collembola in grassland and forest. OIKOS 117, 703-710. https://doi.org/ 10.1111/j.2008.0030-1299.16452.x

St. Laurent, A., Merwin, I.A., Fazio, G., Thies, J.E., and Brown, M.G. (2010). Rootstock genotype succession influences apple replant disease and root-zone microbial community composition in an orchard soil. Plant Soil 337, 259-72. https:// doi.org/10.1007/s11104-010-0522-z

St. Laurent, A., Merwin, I.A., and Thies, J.E. (2008). Long-term orchard groundcover management affect soil microbial communities and apple replant disease severity. Plant Soil 304, 209-225. https://doi.org/10.1007/s11104-008-9541-4

Sun, J., Zhang, Q., Zhou, J., and Wei, Q. (2014). Illumina amplicon sequencing of 16S rRNA tag reveals bacterial community development in the rhizosphere of apple nurseries at a replant disease site and a new planting site. Plos One 9, e111744. https://doi.org/10.1371/journal.pone. 0111744

Tewoldemedhin, Y.T., Mazzola, M., Labuschagne, I., and McLeod, A. (2011). A multi-phasic approach reveals that apple replant disease is caused by multiple biological agents, with some agents acting synergistically. Soil Biol. Biochem. 43, 1917-1927. https://doi.org/10.1016/j.soilbio. 2011.05.014

Tukey, R.B., Dow, A.I., and Halvorson, A.R. (1984). Fertilizer guide - Fruit trees for entire state. Publication FG 0028a. College of Agriculture Washington State University, Pullman, Washington.

Utkhede, R.S. (2006). Soil sickness, replant problem or replant disease and its integrated control. Allelopathy J. 18, 23-38.

Utkhede, R.S., and Smith, E.M. (1992). Promotion of apple tree growth and fruit production by the EBW-4 strain of Bacillus subtilis in apple replant 
disease soil. Can. J. Microbiol. 38(12), 1270-1273. https://doi.org/10.1139/m92-209

Utkhede, R.S., Vrain, T.C., and Yorston J.M. (1992). Effects of nematodes, fungi, and bacteria on the growth of young apple trees grown in apple replant disease soils. Plant Soil 139, 1-6. http:// www.jstor.org/stable/42937909

Van Elsas, J.D., and Heijnen, C.E. (1990). Methods for the introduction of bacteria into soil: a review. Biol. Fert. Soils 90, 127-133. https://doi.org/ 10.1007/BF00336248

Van Schoor, L., Denman, S., and Cook, N.C. (2009). Characterisation of apple replant disease under South African conditions and potential biological management strategies. Sci. Hortic.-Amsterdam 119, 153-162. https://doi.org/10.1016/j.scienta. 2008.07.032

Vasar, M., Andreson, R., Davison, J., Jairus, T., Moora, M., Remm, M., Young, J.P.W., Zobel, M., and Öpik, M. (2017). Increased sequencing depth does not increase captured diversity of arbuscular mycorrhizal fungi. Mycorrhiza 27, 761-773. https:// doi.org/10.1007/s00572-017-0791-y

Venice, F., de Pinto, M.C., Novero, M., Ghignone, S., Salvioli, A., and Bonfante, P. (2017). Gigaspora margarita with and without its endobacterium shows adaptive responses to oxidative stress. Mycorrhiza 27, 747-759. https:// doi.org/10.1007/s00572-017-0790-z

Volk, G.M., Chao, C.T., Norelli, J., Brown, S.K., Fazio, G., Peace, C., McFerson, J., Zhong, G.Y., and Bretting, P. (2015). The vulnerability of US apple (Malus) genetic resources. Genet. Resour. Crop Ev. 62, 765-794. https://doi.org/10.1007/ s10722-014-0194-2

Volk, G.M., Henk, A.D., Richards, C.M., Forsline, P.L., and Chao, C.T. (2013): Malus sieversii. A Diverse Central Asian Apple Species in the USDA-ARS National Plant Germplasm System. HortScience 48, 1440-1444.

Von Bronsart, H. (1949). Der heutige Stand unseres Wissens von der Bodenmüdigkeit. J. Plant Nutr. Soil Sc. 45, 166-193. https://doi.org/10.1002/jpln. 19490450116

Von Lützow, M., Kögel-Knabner, I., Ekschmitt, K., Matzner, E., Guggenberger, G., Marschner, B., and Flessa, H. (2006). Stabilization of organic matter in temperate soils: Mechanisms and their relevance under different soil conditions - A review. Eur. J. Soil Sci. 57, 426-445. https:// doi.org/10.1111/j.1365-2389.2006.00809.x

Voříšková, A., Jansa, J., Püschel, D., Krüger, M., Cajthaml, T., Vosátka, M., and Janoušková, M. (2017) Real-time PCR quantification of arbuscular mycorrhizal fungi: does the use of nuclear or mitochondrial markers make a difference? Mycorrhiza 27, 577-585. https://doi.org/10.1007/ s00572-017-0777-9

Vukicevich, E., Lowery, T., Bowen, P., Urbez-Torres, J. R., and Hart, M. (2016). Cover crops to increase soil microbial diversity and mitigate decline in perennial agriculture. A review. Agronomy for Sustainable Development 36 (3). https://doi.org/10.1007/s13593-016-0385-7

Walter, D.E., and Proctor, H.C. (2013). Mites. Ecology, Evolution and Behaviour; Life at a Microscale $\left(2^{\text {nd }}\right.$ edition, Dordrecht, Netherlands: Springer).

Wang, K.H., and McSorley, R. (2005). Effects of soil ecosystem management on nematode pests, nutrient cycling, and plant health. APSnet Features, 2005-0105. https://doi.org/10.1094/ APSnetFeatures/2005-0105

Wardle, D.A. (2006). The influence of biotic interactions on soil biodiversity. Ecol. Lett. 9, $870-886$. https://doi.org/10.1111/j. 1461-0248.2006.00931.x

Wardle, D.A. (2013). Communities and ecosystems. Linking the aboveground and belowground components. Princeton: Princeton University Press (Monographs in Population Biology). http:// gbv.eblib.com/patron/FullRecord.aspx? $p=1113398$

Weiß, S., Bartsch, M., and Winkelmann, T. (2017a). Transcriptomic analysis of molecular responses in Malus domestica 'M26' roots affected by apple replant disease. Plant Mol. Biol. 94, 303-318. https://doi.org/10.1007/s11103-017-0608-6

Weiß, S., Liu, B., Reckwell, D., Beerhues, L., and Winkelmann, T. (2017b). Impaired defense reactions in apple replant disease-affected roots of Malus domestica 'M26'. Tree Physiol. https:// doi.org/10.1093/treephys/tpx108

Whipps, J.M. (2004). Prospects and limitations for mycorrhizas in biocontrol of root pathogens. Can. J. Bot. 82, 1198-1227. https://doi.org/10.1139/ b04-082

Wiesenberg, G.L.B., Schwarzbauer, J., Schmidt, M.W.I., and Schwark, L. (2004). Sources and turnover of organic matter in agricultural soils derived from n-alkane/n-carboxylic acid compositions and C-isotope signatures. Org. Geochem. 35, 1371-1393. https://doi.org/10.1016/ j.orggeochem.2004.03.009

Willett, M., Smith, T.J., Peterson, A.B., Hinman, H., Stevens, R.G., Ley, T., Tvergyak, P., Williams, K.M., Maib, K.M., and Williams, J.W. (1994). Growing Profitable Apple Orchards in Replant Sites: An Interdisciplinary Team Approach in Washington State. HortTechnology 4, 175-181. 
Wittenmayer, L., and Szabó, K. (2000). The role of root exudates in specific apple (Malus $x$ domestica Borkh.) replant disease (SARD). J. Plant Nutr. Soil Sc. 163, 399-404. https://doi.org/ 10.1002/1522-2624(200008)163:4<399::AIDJPLN399>3.0.CO;2-8

Wrede, A. (2015). Bodenmüdigkeit bei Rosen - Was bringt Zugabe von Trichoderma harzianum? Deutsche Baumschule 11, 37-39.

Yim, B., Hanschen, F.S., Wrede, A., Nitt, H., Schreiner, M., Smalla, K., and Winkelmann, T. (2016). Effects of biofumigation using Brassica juncea and Raphanus sativus in comparison to disinfection using Basamid on apple plant growth and soil microbial communities at three field sites with replant disease. Plant Soil 406, 389-408. https://doi.org/10.1007/s11104-016-2876-3

Yim, B., Nitt, H., Wrede, A., Jacquiod, S., Sørensen, J., Winkelmann, T., and Smalla, K. (2017). Effects of soil pre-treatment with Basamid $₫$ granules, Brassica juncea, Raphanus sativus and Tagetes patula on bacterial and fungal communities at two replant disease sites. Front. Microbiol. 8, 1604. https://doi.org/10.3389/fmicb.2017.01604

Yim, B., Smalla, K., and Winkelmann, T. (2013). Evaluation of apple replant problems based on different soil disinfection treatments-links to soil microbial community structure? Plant Soil 366, 617-631. https://doi.org/10.1007/s11104-012-1454-6
Yim, B., Winkelmann, T., Ding, G.C., and Smalla, K. (2015). Different bacterial communities in heat and gamma irradiation treated replant disease soils revealed by $16 \mathrm{~S}$ rRNA gene analysis contribution to improved aboveground apple plant growth? Front. Microbiol. 6, 1224. https://doi.org/ 10.3389/fmicb.2015.01224

Yin, C., Xiang, L., Wang, G., Wang, Y., Shen, X., Chen, X., and Mao, Z. (2016). How to plant apple trees to reduce replant disease in apple orchard: A study on the phenolic acid of the replanted apple orchard. Plos One 12, e0167347. https:// doi.org/10.1371/journal.pone.0167347

Yin, C., Xiang, L., Wang, G., Wang, Y., Shen, X., Chen, X., and Mao, Z. (2017). Phloridzin promotes the growth of Fusarium moniliforme (Fusarium verticillioides). Sci. Hortic.-Amsterdam 214, 187-194. https://doi.org/10.1016/j.scienta. 2016.11.035

Zhu, Y., Fazio, G., and Mazzola, M. (2014). Elucidating the molecular responses of apple rootstock resistant to ARD pathogens: challenges and opportunities for development of genomicsassisted breeding tools. Horticulture Research 1, 14043. https://doi.org/10.1038/hortres.2014.43 
